\section{Respiratory Event Index}

Helga Peter

Marburg, Deutschland

\section{Synonyme}

REI

\section{Definition}

Bezeichnet im Out of Center Sleep Testing (OCST) die Gesamtmenge der relevanten respiratorischen Ereignisse multipliziert mit 60 und geteilt durch die Aufzeichnungszeit in Minuten. 